normal haemoglobin and in the anaemic patients reported here and elsewhere ${ }^{3}$ argues against a causative role for glucagon in the anaemia of end-stage renal disease.

We are grateful to Dr Nina C Mendoza for allowing us to study patients under her care.

${ }^{1}$ Mallinson, C N, et al, Lancet, 1974, 2, 1.

2 Bilbray, G L, et al, fournal of Clinical Investigation, 1974, 53, 841

${ }^{3}$ Trimble, E R, et al, New Zealand Medical fournal, 1976, 83, 357.

${ }^{4}$ Unger, R H, et al, fournal of Clinical Investigation, 1961, 40, 1280.

${ }^{5}$ Eaton, R P, American fournal of Physiology, 1973, 225, 67.

(Accepted 2 March 1978)

Christ Hospital, Division of Nephrology, Cincinnati, Ohio 45219

JOSEPH MCEVOY, MD, MRCP

University of Cincinnati Medical Centre, Division of Digestive

Diseases, Cincinnati, Ohio 45267

ANNE MARY MCCARROLL, MD, MRCP

\section{Shwachman's syndrome and acute lymphoblastic leukaemia}

The association of hypoplasia of the exocrine pancreas and bone marrow dysfunction has been recognised since $1964 .{ }^{1} \mathrm{~A}$ wide range of haematological disorders has been described, but we report a new association-acute lymphoblastic leukaemia.

\section{Case report}

A 14-year-old boy presented with a two-month history of recurrent ches infections. Despite antibiotic treatment he had deteriorated with increasing weight loss, pallor, and breathlessness. His medical history was unremarkable with no symptoms suggestive of a bowel disorder, although his sister had died aged 9 years of suspected coeliac disease. On admission he was pale and small for his age; his abdomen was protruberant with ascites; and his ankles swollen. He had generalised lymphadenopathy and gross hepatosplenomegaly. The results of initial investigations showed haemoglobin $5.2 \mathrm{~g} / \mathrm{dl}$, total white cell count $525 \times 10^{9} / 1$ with neutrophils $2 \%$ and blast cells $98 \%$. Plasma concentration of sodium was $134 \mathrm{mmol} / 1(134 \mathrm{mEq} / \mathrm{l})$ potassium $3.4 \mathrm{mmol} / 1(3.4 \mathrm{mEq} / \mathrm{l})$, urea $43 \mathrm{mmol} / 1(257 \mathrm{mg} / 100 \mathrm{ml})$, uric acid $0.3 \mathrm{mmol} / 1(5.0 \mathrm{mg} / 100 \mathrm{ml})$, bilirubin $11 \mu \mathrm{mol} / 1(0.6 \mathrm{mg} / 100 \mathrm{ml})$. Serum albumin was $38 \mathrm{~g} / \mathrm{l}$ and globulins $27 \mathrm{~g} / 1$; immunoglobulin concentrations were normal. Chest $x$-ray films showed chronic infective changes but no mediastinal widening. Bone marrow aspirate was hypercellular because of a dense infiltrate of blast cells which showed "block" periodic acid Shiff positivity but no myeloperoxidase activity. The abnormal cells also reacted with an antibody raised against leukaemic lymphoblasts.

Acute lymphoblastic leukaemia was diagnosed and he was entered into the appropriate MRC trial. Initial treatment was with intravenous vincristine $1.5 \mathrm{mg}$ weekly and oral prednisolone $40 \mathrm{mg}$ daily. The primitive cells disappeared from the peripheral blood within six days. During the ensuing pancytopenia he developed epistaxis and gastrointestinal bleeding necessitating frequent transfusions of red cells and platelets. He also developed a severe klebsiella pneumonia, which persisted despite appropriate antibiotic treatment. Diuretics caused a rapid disappearance of the peripheral oedema but the ascites increased. In the later stages of his illness he also developed persistent offensive diarrhoea. He died six weeks after treatment was started, still in a stage of profound pancytopenia. Bone marrow examination five days before death showed severe hypoplasia of the normal marrow tissue but no evidence of active leukaemia.

Postmortem examination showed consolidation of both lungs and evidence of massive gastrointestinal haemorrhage. The liver and spleen were enlarged, the liver histologically showing increased fibrosis. There was no sign of residual leukaemia in the liver or any other organ examined. The most striking histological abnormality was the total absence of exocrine pancreatic tissue, the islet cells being surrounded by fatty tissue with a few dilated ducts.

\section{Comment}

Though rare, hypoplasia of the exocrine pancreas is said to be the most common pancreatic disorder of childhood once cystic fibrosis has been excluded. ${ }^{2}$ Haematological abnormalities described in association with this condition include anaemia, neutropenia, and thrombocytopenia, and bone marrow examinations have shown hypoplasia or a maturation arrest in one or more cell lines. ${ }^{12}$ Orily two cases have been described in association with leukaemia: one monocytic $^{3}$ and the other myeloblastic. ${ }^{4}$ The association with lymphoblastic leukaemia is more difficult to explain. Lymphoreticular malignancy in patients with immunoglobulin deficiency is well recognised and some cases of Shwachman's syndrome have recently been described with low immunoglobulin concentrations." In our case, however, the immunoglobulin concentrations were normal.

Shwachman's syndrome is often familial ${ }^{12}$ and interestingly ou patient's sister had died with a malabsorption syndrome. There was no evidence from the biopsy specimen of coeliac disease and she failed to respond to a gluten-free diet, so probably she also had pancreatic hypoplasia.

Requests for reprints should be addressed to Dr J S Lilleyman.

1 Shwachman, H, et al, fournal of Pediatrics, 1964, 65, 645

${ }^{2}$ Burke, V, et al, Archives of Disease in Childhood, 1967, 42, 147.

${ }^{3}$ Nezelof, C, and Watchi, M, Archives Françaises de Pédiatrie, 1961, 18, 1135.

${ }^{4}$ Huijgens, P C, et al, Scandinavian fournal of Haematology, 1977, 18, 20 ${ }^{5}$ Hudson, E, and Aldor, T, Archives of Internal Medicine, 1970, 125, 314

(Accepted 2 March 1978)

Children's Hospital, Sheffield S10 2TH

$M$ J STREVENS, MB, MRCP, senior registrar in haematology

J S LILLEYMAN, MRCP, MRCPATH, consultant haematologist

R B WILLIAMS, BSC, MB, senior registrar in histopathology

\section{Deaths in cold water}

Most efforts to reduce the heavy loss of life in water accidents are directed to improving the ability to swim, but a recent Home Office report of the Working Party on Water Safety gives further emphasis to the fact that many of the people who die can swim. Of those whose swimming ability was known, most of those in the 15- to 35-year-old age group who died could swim, while most of those who died in the sea at any age were either good or very good swimmers. It is still not always realised that even summer waters around Britain are cold enough to kill during prolonged immersion, and that in winter and spring the high viscosity and other effects of water near $0^{\circ} \mathrm{C}$ can cause excellent swimmers to drown in as little as 90 seconds. ${ }^{1}$ Advice about simple precautions to be taken in cold water, which can prevent or greatly reduce these hazards, was widely distributed by water sport clubs and schools after a conference organised by the Central Council for Physical Recreation in 1971. We have now analysed the Registra General's Statistical Reviews to see whether this action was followed by any major changes in the accident rates.

\section{Statistical analysis}

The table shows the deaths in different age groups during the four years up to and the four years after 1971. The deaths are those registered as definitely accidental and due to sinking of boats, falling from boats, and othe drownings and submersions (categories E830, E832, and E910) for England and Wales only. They show that the number of deaths fell significantly ( $\mathrm{P}<0.001$ by the $\chi^{2}$ test), in the 5 - to 14 -year-old age group only. The total deaths in the group were 549 in 1968-71 (18.3/million) and 438 in 1972-5 (13.9/million). This represents a reduction of 111 deaths or a little more if the

Accidental deaths in water

\begin{tabular}{c|c|c|c|c}
\hline \multirow{2}{*}{ Age } & \multicolumn{2}{|c|}{$1968-71$} & \multicolumn{2}{|c}{$1972-5$} \\
\cline { 2 - 4 } & $\begin{array}{c}\text { Total } \\
\text { deaths }\end{array}$ & $\begin{array}{c}\text { Deaths } \\
\text { million }\end{array}$ & $\begin{array}{c}\text { Total } \\
\text { deaths }\end{array}$ & $\begin{array}{c}\text { Deaths/ } \\
\text { million }\end{array}$ \\
\hline $0-4$ & 400 & $24 \cdot 7$ & 337 & $23 \cdot 1$ \\
$5-14$ & $549^{*}$ & $18 \cdot 3$ & $438^{*}$ & 13.9 \\
$15-44$ & 879 & 11.5 & 864 & $11 \cdot 3$ \\
$45-64$ & 346 & 7.3 & 345 & 7.4 \\
$65+$ & 233 & $9 \cdot 3$ & 268 & 9.9 \\
\hline
\end{tabular}

*Figures for 1968-71 differ from those for 1972-5 $\mathrm{P}<0.001$. 
increased population in this age group is taken into account. Accident rates per million population at risk in all other age groups were remarkably similar between the two periods.

\section{Comment}

The fact that the improvement was confined to school-age children shows that measures taken between these periods had a major impact on this age group, which is that most exposed to advice and perhaps the group most receptive to it. Other water safety measures than those instituted by the 1971 conference were taken or increased at about this time and the improvement is likely to have resulted from severa factors, including better training in swimming. Whatever the precise contribution of these, the figures make it clear that older and younger age groups were not effectively reached by any of the measures taken to reduce deaths in water. The high proportion of good swimmers among those who die suggests that many may be made over-confident by their swimming ability and be unaware of the specific dangers of cold water and how to minimise them.

Additional measures are clearly needed to reduce the death rates in those over 15. Warnings such as those which the BBC broadcast recently, when weather forecasts predicted particularly hazardous combinations of sunny weather and cold water, may be the best way of catching people's attention at relevant times. These could be reinforced by compulsory attachment of brief warning notices to all new small craft and all ships' bridges, giving advice about survival in cold water. Both the broadcast warnings and notices could include advice always to wear lifejackets in small craft in cold waters; if immersed, to float still rather than swim about, and to keep on warm clothing as well as a lifejacket in the water ${ }^{2}$; and never to take even small quantities of alcoholic drinks after exercise in exposed conditions unless a large meal is eaten at the same time."

Traditional campaigns to teach swimming should certainly still be encouraged and extended to the youngest possible age groups. Nevertheless, there seems a special need to tackle the high accident rate among those who can swim but are unaware that it has limited power to preserve life-and in fact often hastens death in cold water.

${ }^{1}$ Keatinge, W R, et al, British Medical fournal, 1969, 1, 480.

${ }^{2}$ Keatinge, W R, Survival in Cold Water: the Physiology and Treatment of Immersion Hypothermia and Drowning. Oxford, Blackwell, 1969.

${ }^{3}$ Haight, J S J, and Keatinge, W R, fournal of Physiology, 1973, 229, 87.

(Accepted 2 March 1978)

Department of Physiology, London Hospital Medical College, London E1 2AD

J M GRAHAM, BM, PHD, lecturer

W R KEATINGE, MB, PHD, professor metronidazole $4.2 \mathrm{~g}$ for recurrence of abdominal symptoms. One month after the third course numbness of fingers and toes developed and slight pressure on nerves produced tingling and numbness. This implicated the peroneal and ulnar nerves, and several times he awoke with a wristdrop lasting for several minutes. Modest alcohol intake induced transient numbness distally, sometimes spreading up the arms and legs. There was numbness to pin prick of the toes and fingers but no other signs.

The results of nerve conduction studies were normal, but electromyography showed denervation of distal muscles. Denervation atrophy was present in the left peroneus brevis. Histological appearances of the sural nerve were normal on light microscopy but electron microscopy showed an excess of collagen fibres, consistent with a chronic neuropathy. Duodenal histology and faecal fat excretion were normal. Six months after onset of his neurological symptoms he was given $6 \mathrm{~g}$ metronidazole for 10 days. Three months later the neurological symptoms rapidly improved. He has remained asymptomatic for 13 months.

\section{Comment}

A causal rather than a chance association of giardiasis and peripheral neuropathy is suggested by the failure to identify an alternative cause of neuropathy; the striking similarity in the two patients of the symptoms, signs, investigative findings, and clinical course; and the return to normal of neurological symptoms after treatment for giardiasis. Malabsorption, a recognised cause of peripheral neuropathy ${ }^{1}$ and common in giardiasis, is a possible explanation for the neuropathy. Our first patient had steatorrhoea, but faecal fat excretion in the second patient was not estimated before the giardiasis was treated. Serum folate and vitamin $\mathrm{B}_{12}$ concentrations and radioactive vitamin $B_{12}$ absorption were normal in both when they presented with neurological symptoms. Deficiency of other vitamins was not investigated.

Metronidazole is unlikely to have contributed to the neurological symptoms in our two cases since in all patients so far reported the dose has been much larger than that given to our patients. ${ }^{2-4}$ Furthermore, both improved after receiving further courses of the drug.

If further studies indicate a firmer link between peripheral neuropathy and intestinal giardiasis, patients with peripheral neuropathy of no apparent cause should be screened for giardiasis because gastrointestinal symptoms may be absent, as in case 1. Furthermore, giardiasis is easily treated, and may be another treatable cause of peripheral neuropathy.

We thank Professors B A Kakulas and R McD Anderson for electron microscopy of the sural nerves.

Requests for reprints should be addressed to Dr G Danta.

${ }^{1}$ Cooke, W T, and Smith, W T, Brain, 1966, 89, 683.

2 Schipper, H, et al, New England fournal of Medicine, 1976, 295, 901.

${ }^{3}$ Coxon, A, and Pallis, C A, Fournal of Neurology, Neurosurgery and Psychiatry, 1976, 39, 403.

${ }^{4}$ Bradley, W G, et al, British Medical fournal, 1977, 2, 610.

(Accepted 15 March 1978)

Neurology Unit, Canberra Hospital, Acton, ACT 2601, Australia

M L BASSETT, MB, CHB, gastroenterology registrar

G DANTA, FRACP, MRCP, director, neurology unit

T A COOK, MRCPATH, FRCPA, pathologist

Comprehensive investigation of two patients showed no cause for their peripheral neuropathy. Both had giardiasis, and the neurological symptoms resolved after treatment of the infestations.

\section{Case reports}

Case 1-A man aged 27 years had had progressive numbness and painful paraesthesiae of the feet for 9 months. Toe dorsiflexion was weak and the feet were numb distally. Reflexes and the results of motor and sensory conduction studies were normal, but distal muscles showed denervation. The peroneus brevis showed denervation atrophy. Histological appearances of the sural nerve were normal by light and electron microscopy. Three-day faecal fat excretion was $29.5 \mathrm{~g}$ (normal $<18 \mathrm{~g}$ ). Small-bowel biopsy showed normal findings; numerous motile Giardia lamblia trophozoites were seen in the duodenal aspirate. After treatment with $4.2 \mathrm{~g}$ metronidazole for 7 days the faecal fat excretion became normal. The neurological symptoms gradually improved after 4 months. The course of metronidazole was repeated after a year and the symptoms and signs completely resolved shortly after. He has remained asymptomatic for 18 months

Case 2-A man aged 33 years had had intermittent diarrhoea and abdominal discomfort for eight years. Stools contained $G$ lamblia cysts, and he fully recovered after treatment with $8.4 \mathrm{~g}$ metronidazole for 14 days. Eighteen months later he required two further courses one month apart of

\section{Ankylosing spondylitis presenting as PUO*}

Constitutional disturbances have been reported in ankylosing spondylitis but are usually minor. Fever is usually absent or slight, rarely exceeding $38^{\circ} \mathrm{C}$. We have recently seen four patients with ankylosing spondylitis, presenting with severe constitutional upset, high fever, weight loss, and disease of the hip joints. All showed a good response to phenylbutazone and all were positive for the HLAB27 antigen.

*Based on a paper at the Joint Heberden/British Association for Rheuma tology and Rehabilitation/RSM Section of Rheumatology and Rehabilitation/ Irish Society for Rheumatology and Rehabilitation Meeting, Carlisle, 13-14 October 1977. 